\title{
Evaluation of Pole-type French Bean (Phaseolus vulgaris L.) Genotypes for Agro-Morphological Variability and Yield in the Mid-Hills of Nepal
}

\author{
Santosh Kalauni ${ }^{1 *}$, Salina Pant ${ }^{2}$, Binod P Luitel ${ }^{1}$ and Bishnu Bhandari ${ }^{1}$ \\ ${ }^{1}$ Horticulture Research Station-NARC, Dailekh, Nepal \\ ${ }^{2}$ Agriculture and Forestry University-AFU, Chitwan, Nepal \\ *Corresponding Author: Santosh Kalauni, Horticulture Research Station-NARC, Dailekh, Nepal.
}

Received: November 22, 2019; Published: November 29, 2019

DOI: 10.31080/ASAG.2019.03.0733

\begin{abstract}
Knowledge of genetic diversity is crucial to assess the variability of genotypes and their potential use in crop improvement programs. The present experiment was conducted at Horticulture Research Station (HRS), Dailekh (1300 masl) for three years during 2016-2018 to study the agro-morphological variability and performance of six genotypes of French bean (Phaseolus vulgaris L.) for pod and seed yield. The genotypes viz. Bhatte, Chaumase, Dhankute Chirrke, WP Con Bean, White OP and, Trishuli were experimented in Randomized Completely Block (RCB) design with four replications. Observations were recorded on 14 qualitative and 12 quantitative traits. Among the qualitative traits, French bean genotypes observed variability for stem pigmentation, leaf color, leaflet shape, stem hairiness, flower color, pod color, pod shape, pod cross-section, pod beak position, pod appearance, seed size, seed shape and, seed color. Analysis of variance for quantitative traits showed significant differences among all the genotypes for all the characters studied. Three year mean results showed the genotype Chaumase (35.0 t/ha) followed by Trishuli (28.0 $\mathrm{t} / \mathrm{ha})$, WP Con Bean (24.6 t/ha) and White OP (22.9 t/ha) recorded the maximum green pod yield. Similarly, genotypes Chaumase (2.1 t/ha), Trishuli (2.1 t/ha), Dhankute Chirrke (1.44 t/ha) and White OP (1.09 t/ha) were found promising for seed production purpose. The agro-morphological variation observed in growth and pod characters could be utilized in varietal improvement programs. Future research work needed to be focused on the further evaluation of these genotypes under different production systems for yield and seed production and to identify traits useful for crop improvement.
\end{abstract}

Keywords: Crop Improvement; Genotypes; Pod Yield; Seed Yield

\section{Introduction}

French bean (Phaseolus vulgaris L.), the oldest domesticated plant species is a native crop of Central and South America [1]. It is also known as a common bean, snap bean, kidney bean, and haricot bean. The common bean is predominantly self-pollinated diploid annual species $(2 \mathrm{n}=\mathrm{x}=22)$. The green pods are nutritionally rich containing on an average of $1.7 \%$ protein, $4.5 \%$ carbohydrate, $1.8 \%$ fiber, calcium $50 \mathrm{mg}$, magnesium $28 \mathrm{mg}$ and iron $1.7 \mathrm{mg}$ per 100 gm of pod [2]. Apart from protein, French bean also contains vitamins and minerals which can help to partial alleviation of the malnutrition problem. It is majorly cultivated for its tender pods as vegetable, dried seeds used as pulse and the foliage is used as fodder for animals [3]. In Nepal, it is cultivated in a wide range of agroclimatic conditions and different season from $300 \mathrm{~m}$ to 2,500 masl [4]. Both pole and bush-type French beans are cultivated in the hilly region (500-1600 masl) for green pods during summer to autumn. These beans are grown as a mono-crop in the commercialized peri-urban areas using staking for pole beans or intercropped with maize as a rain-fed crop in the hills. Farmers regard beans as a cash-generating crop in the hills and grow several landraces with 
varying morphologies [5]. The current research was initiated with the objectives of collection, evaluation, and characterization of available exotic and indigenous germplasm for their pod and seed yield potential.

\section{Materials and Methods}

Field experiment was conducted at Horticulture Research Station, Dailekh during winter season (Aug-Dec) for three years 2016/17, 2017/18 and 2018/19 to evaluate the agromorphological, yield and yield attributing characters of popular and potential genotypes of French bean. The station located at a latitude of 28o $13^{\prime} 6.18$ " $\mathrm{N}$ and a longitude of 830 58'27.72" $\mathrm{E}$ is characterized by subtropical climate with an elevation of 1300 masl. The climatic data of the location viz. precipitation, relative humidity, maximum and minimum temperature for three years period are presented in figures $1 \mathrm{a}, 1 \mathrm{~b}$, and $1 \mathrm{c}$. The experiment was arranged in a Randomized Complete Block (RCB) design with four replications; each replication was presented in a four-row plot. Seeds were sown with $75 \mathrm{~cm}$ row to row and $25 \mathrm{~cm}$ plant to plant distance. Manure and fertilizer were applied as compost (20 t/ha) and 40:60:50 $\mathrm{kg} \mathrm{ha}^{-1} \mathrm{~N}$, P, and K respectively. Gap filling was carried out after 8th day of sowing and 32 plants were maintained in each plot. Within the plot, six plants were randomly taken and tagged for recording observations. Pods were harvested at the time of marketable maturity for recording the observations. Scoring of agro-morphological characters viz. stem pigmentation, leaf color, leaflet shape, stem hairiness, flower color, pod color, pod shape, pod cross-section, pod beak position, pod pubescence, pod appearance, seed size, seed shape and seed color was done according to the procedures given in the IBPGR (International Board for Plant Genetic Resources) descriptors for Phaseolus vulgaris [6]. The quantitative observations recorded for the experiment were namely germination percentage, pod length $(\mathrm{cm})$, pod diameter $(\mathrm{mm})$, individual pod weight $(\mathrm{g})$, seeds pod $^{-1}$, green pods plant ${ }^{-1}$, green pod yield plant ${ }^{-1}(\mathrm{~kg})$, green pod yield per hectare $(\mathrm{t})$, dry pods plant ${ }^{-1}$, dry pod yield plant ${ }^{-1}(\mathrm{~g})$, seed yield (t/ha) and 100 seeds weight $(\mathrm{g})$. The qualitative characters/traits were measured by a team of 10-15 experts and consumers. The pod length and pod diameter were measured with the help of meter-scale and vernier caliper respectively. Germination percentage is calculated by Pooled mean values of the parameters in each replication were statistically analyzed through R programming [7]. Statistical testing was carried out using Duncan's new multiple range test at the $\mathrm{P}<$ 0.05 level. Microsoft Excel was used for plotting figures, and graphs.

Germination Percentage $=\frac{\text { No of germinated seedings }}{\text { Total number of seeds }} \times 100$

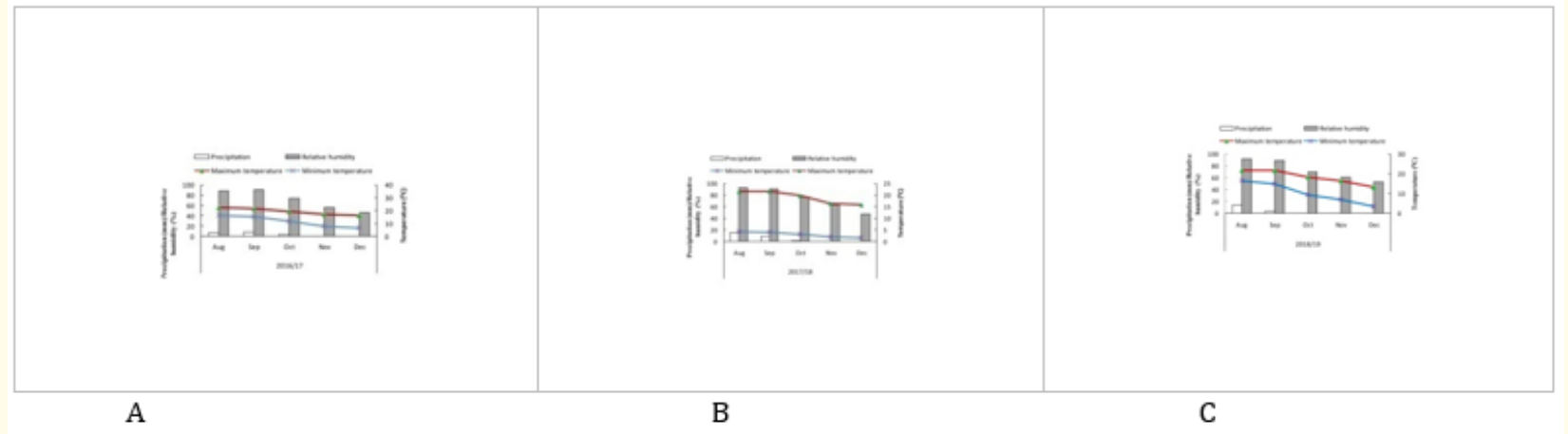

Figure 1a: Precipitation (mm), relative humidity, minimum temperature (0C) and maximum temperature (0C) pattern from Aug-Dec at HRS, Dailekh of Nepal in 2016/17.

Figure 1b: Precipitation (mm), relative humidity, minimum temperature (0C) and maximum temperature (0C) pattern from Aug-Dec at HRS, Dailekh of Nepal in 2017/18.

Figure 1c: Precipitation (mm), relative humidity, minimum temperature (0C) and maximum temperature (0C) pattern from Aug-Dec at HRS, Dailekh of Nepal in 2018/19. 


\section{Results and Discussion}

Agro-morphological Attributes

Stem pigmentation

Stem pigmentation is a useful DUS trait for classifying and differentiating genotypes. The data on stem pigmentation of six genotypes are presented in Table 1. Among the genotypes, Bhatte, Dhankute Chirrke, White OP and Trishuli had green pigmentation on stem, Chaumase had green with red streaks and WP Con Bean had green with purple stem pigmentation. Among the 15 genotypes of Dolichos bean studied for stem pigmentation, four genotypes were light green stem color, four genotypes purple stem and seven genotypes dark purple stem [8]. Fifteen Jack bean genotypes were categorized based on stem color into three groups viz., light green, purple and dark purple [9].

\section{Leaf color}

Leaf colors in beans are categorized as pale green, green, and dark green. Among the six, three genotypes namely Bhatte, Dhankute Chirrke, and WP Con Bean had pale green leaf color. Chaumase and Trishuli produced the dark green whereas White OP had green leaf color (Table 1). Similar findings have been reported by other researchers. Leaf color intensity of hyacinth bean varied from pale green to green to dark green [10]. Studying the leaf color, only green and purple vein colors among 107 hyacinth bean genotypes were observed and leaf color intensity varied from pale green to green to dark green [11].

\section{Leaflet shape}

Leaflet shape is a certifying DUS characteristic for distinguishing genotypes. The data on the leaflet shape of six genotypes observed are presented in Table 1. The leaflet shape of five genotypes namely Bhatte, Chaumase, WP Con Bean, White OP, and Trishuli was round while Dhankute Chirrke had ovate form of leaflet shape. Similar classification of soybean varieties and hyacinth bean genotypes was observed based on leaflet shape [10,12]. Fifteen genotypes of Jack bean based on leaf density was categorized as sparse, intermediate and dense [9].

Hairiness on the stem

Data on hairiness on the stem of French bean genotypes are presented in Table 1. Out of the six, three genotypes namely Bhatte, WP Con Bean and White OP had glabrous (without hairs) whereas the genotypes Chaumase, Dhankute Chirrke, and Trishuli had sparse hairiness. Seven French bean genotypes based on seedling pubescence was categorized as glabrous and dense [13].

\section{Flower color}

Flower color is an important DUS characteristic that offers a quick and easy identification module for characterizing genotypes. The petal color of four genotypes namely, Bhatte, WP Con Bean, White OP, and Trishuli had white color whereas Chaumase had lilac and Dhankute Chirrke had violet-purple petal color. Similarly, 284 bean accessions were studied and categorized them into three group viz., white, plain red to dark lilac and purple colored flowers [14].

\section{Pod shape}

Pod shape influences the consumer preference in the market and also qualifies as distinguishing DUS trait. The data on the pod shape of French bean genotypes are presented in Table 1. Among six French bean genotypes studied for pod shape, Bhatte and Dhankute Chirrke had straight pods; Chaumase, WP Con Bean and White OP produced slightly curved and Trishuli produced recurring pods. The study of French bean genotypes found most of the genotypes had straight pods and a few had slightly curved pods [15]. Among the eighty accessions of local and exotic bean germplasm for pod curvature on fully expanded immature pods, 43 accessions were slightly curved, 29 were straight and 7 accessions were curved [16].

\section{Pod color}

Pod color is an important NBPGR crop descriptor for classifying and distinguishing genotypes. The data on pod color at an immature stage of French bean genotypes are presented in Table 1. Among the six genotypes, normal green pods were observed in Bhatte, Chaumase, and Trishuli, light green were recorded in WP Con Bean and White OP and green with red stripes were obtained in Dhankute Chirrke. A similar way of classification was done based on pod color $[10,14]$.

\section{Pod cross section}

Data on pod cross-section of French bean genotype are presented in Table. Among six genotypes studied for pod cross-section, Bhatte and Dhankute Chirrke were very flat and Chaumase, WP Con Bean, White OP, and Trishuli had round elliptic pod cross-section.

\section{Pod beak position}

The data on pod beak position of French bean genotype are presented in Table. Among six genotypes studied for pod beak position, Bhatte, Chaumase, WP Con Bean, White OP, and Trishuli had marginal beak and Dhankute Chirrke had non-marginal beak position. 
Evaluation of Pole-type French Bean (Phaseolus vulgaris L.) Genotypes for Agro-Morphological Variability and Yield in the Mid-Hills of Nepal

Pod pubescence

Data on hairiness on pod of French bean genotype are presented in Table 1. Among six French bean genotypes studied for hairiness on pod, all genotypes were glabrous (without hairs) type. Pod surface in 15 French bean genotypes was observed and reported as smooth pod surface in eight genotypes and pubescent pod surface in the remaining seven genotypes [17].

\section{Seed size}

Classifying genotypes on the basis of seed size is important for designing future breeding strategy for fulfilling the selective market needs of concerned community. The data on seed size of six French bean genotypes are presented in Table 1. The genotype Bhatte, and White OP had large seed size; Trishuli had medium and Chaumase, Dhankute Chirrke and WP Con Bean had small size seed. Thirty two French bean cultivars and classified them on the basis of 100 seed weight ranging from 18.4 to $50.6 \mathrm{~g}$ [18]. Similarly, eighteen different germplasm accessions of hyacinth bean (Lablab purpureus) and reported the seed sizes ranged from 5.7 to 14.3 $\mathrm{mm}$ in length and 4.0-8.6 mm in width [19].

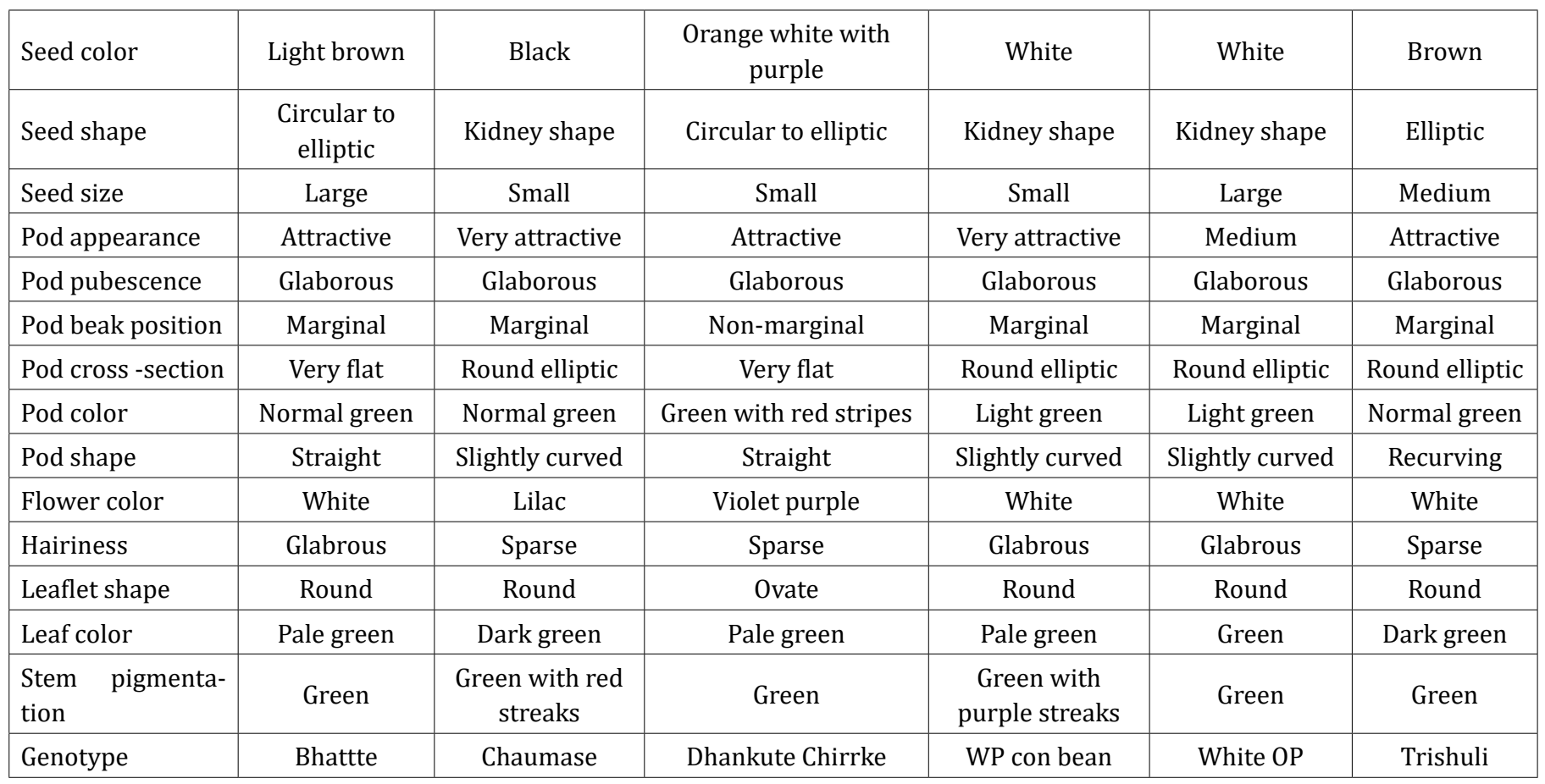

Table 1: Plant, leaf, flower and pod characteristics of different genotypes of French bean at HRS, Dailekh in 2016-2018.

\section{Seed shape}

Seed shape influences the consumer preference in the market. Therefore, to meet out the aspirations of the market it becomes essential to screen out and classify the genetic stock as per the market orientation. Among the six genotypes, Bhatte and Dhankute Chirkke had circular to elliptic seed shape; Chaumase, WP Con bean, and White OP had kidney shape and Trishuli had elliptic seed shape (Table 1). Eighteen French bean varieties collected from ICAR institutes and SAUs were reported circular to elliptic, kidney and elliptic and seed shape [20]. Similarly, twentytwo common bean genotypes were observed as round, oval, kidney and cuboid shape [21].

\section{Seed coat color}

Seed coat color is an identification indicator and useful trait to the distinctness of a genotype. The genotypes under study produce different color as light brown, black, orange white and purple, white and brown. In the present study, different French bean genotypes observed varied seed coat color. Chaumase produced black seed color. White OP and WP Con Bean white color seed coat whereas Trishuli alone produced brown seed coat. Bhatte and Dhankute Chirrke produced light brown and orange white with purple respectively (Table 1 ). Seed coat color was used to distinguish 80 accessions of bean germplasm [16]. Examination identified 
Evaluation of Pole-type French Bean (Phaseolus vulgaris L.) Genotypes for Agro-Morphological Variability and Yield in the Mid-Hills of Nepal

different color patterns viz., pink, purple, ash, cream, yellow, maroon, black, violet, shining purple and red among different seed samples. Similarly, the diversity of common bean landraces classified based on seed color [22,23].

Yield and yield attributes

Germination percentage

Pooled data of three years revealed that germination percentage differs significantly among the French bean genotypes (Table 2). The genotypes which showed relatively higher germination percentage were Bhatte (93.8\%) and Chaumase (93.2\%). However, the lowest values of these attributes were associated with White OP (84.0\%) and WP Con Bean (84.2\%). Relatively higher germination percentage in some genotypes may be due to the bold seed character of the genotype.

Pod length, pod width and individual pod weight

The pooled analysis of three-year data revealed that pod length, pod width, and individual pod weight differed considerably among the genotypes (Table 2 and Table 3). Significantly highest pod length was observed for the genotype Trishuli $(19.3 \mathrm{~cm})$ and lowest for Dhankute Chirrke $(11.3 \mathrm{~cm})$. In general consideration, it can be concluded from the result that genotypes Trishuli, Chaumase, White OP and WP Con Bean produced relatively longer pods whereas the genotypes like Bhatte and Dhankute Chirrke have relatively smaller pod length. Highest pod diameter was measured as $11.9 \mathrm{~mm}$ from the genotype Bhatte and lowest from WP Con Bean ( $9.5 \mathrm{~mm})$ and White OP (9.5 mm), statistically identical to each other. Genotypes like Chaumase, Trishuli and Dhankute Chirrke having intermediate pod diameter ranging from $9.6 \mathrm{~mm}$ to $11.7 \mathrm{~mm}$. The genotypes included in the study obtained an average variation of individual pod weight from $8.7 \mathrm{~g}$ to $14.7 \mathrm{~g}$. Among the genotypes, Trishuli measured the highest individual pod weight (14.7 g) followed by Chaumase (13.3 g). The lowest value was recorded for Dhankute Chirrke (8.7 g).

The variation in pod length, pod width and individual pod weight of French bean genotypes observed in the present study may be due to their inherited traits and to some extent by environmental factors. Similarly, variability in different varieties of French bean was observed for pod length and pod width [4] [24]. Similarly, variation for pod length and pod width was observed in varieties of hyacinth bean [10] and lablab bean [25].

\begin{tabular}{|c|c|c|c|c|c|c|c|c|c|c|c|c|}
\hline \multirow[b]{2}{*}{ Geotypes } & \multicolumn{4}{|c|}{ Germination Percentage (\%) } & \multicolumn{4}{|c|}{ Pod length (cm) } & \multicolumn{4}{|c|}{ Pod width (mm) } \\
\hline & $\begin{array}{c}2015 \\
/ 16 \\
\end{array}$ & $\begin{array}{c}2016 \\
/ 17\end{array}$ & $\begin{array}{c}2017 \\
/ 18\end{array}$ & Mean & $\begin{array}{c}2015 \\
/ 16\end{array}$ & $\begin{array}{c}2016 \\
/ 17\end{array}$ & $\begin{array}{c}2017 \\
/ 18\end{array}$ & Mean & $\begin{array}{c}2015 \\
/ 16\end{array}$ & $\begin{array}{c}2016 \\
/ 17\end{array}$ & $\begin{array}{c}2017 \\
/ 18\end{array}$ & Mean \\
\hline Bhattte & 92.2 & 91.4 & 97.9 & $93.8 \mathrm{a}$ & 12.9 & 13.8 & 12.0 & $12.9 \mathrm{~d}$ & 10.5 & 14.8 & 10.3 & $11.9 \mathrm{a}$ \\
\hline Chaumase & 97.7 & 85.1 & 96.9 & $93.2 \mathrm{a}$ & 16.7 & 17.7 & 15.9 & $16.7 \mathrm{~b}$ & 10.1 & 9.7 & 9.1 & $9.6 \mathrm{c}$ \\
\hline $\begin{array}{l}\text { Dhankute } \\
\text { Chirrke }\end{array}$ & 94.5 & 75.7 & 94.8 & 88.4ab & 10.9 & 12.3 & 10.5 & $11.3 \mathrm{e}$ & 10.5 & 14.2 & 10.4 & $11.7 \mathrm{a}$ \\
\hline $\begin{array}{l}\text { WP Con } \\
\text { Bean }\end{array}$ & 92.2 & 68.7 & 91.7 & $84.2 \mathrm{~b}$ & 15.7 & 18.8 & 13.4 & $15.9 \mathrm{c}$ & 10.2 & 9.2 & 9.1 & $9.5 \mathrm{c}$ \\
\hline White OP & 91.4 & 77.3 & 8.3 & $84.0 \mathrm{~b}$ & 16.3 & 17.4 & 13.9 & $15.9 \mathrm{c}$ & 10.0 & 9.2 & 9.2 & $9.5 \mathrm{c}$ \\
\hline Trishuli & 99.4 & 78.9 & 97.9 & $92.1 \mathrm{a}$ & 18.6 & 21.3 & 18.1 & 19.3a & 10.3 & 11.2 & 10.6 & $10.7 \mathrm{~b}$ \\
\hline Mean & 90.5 & 78.4 & 93.2 & 89.3 & 15.2 & 16.9 & 14.0 & 15.4 & 10.3 & 11.4 & 9.7 & 10.5 \\
\hline F-value & & & & $0.001 *$ & & & & $<0.001^{* *}$ & & & & $<0.001^{* *}$ \\
\hline $\begin{array}{l}\text { LSD } \\
(0.05)\end{array}$ & & & & 5.3 & & & & 1.03 & & & & 0.36 \\
\hline CV (\%) & & & & 7.2 & & & & 4.8 & & & & 4.1 \\
\hline
\end{tabular}

Table 2: Performance of different genotypes of French bean for germination percentage, pod length and pod width at HRS, Dailekh during 2016-2018.

Note: NS, * and ** indicate non-significant, significant at $\mathrm{P}<0.05$, and $\mathrm{P}<0.01$, respectively. Means followed by the same letter ( $\mathrm{s}$ ) in the column are not significantly different at $5 \%$ by DMRT. 
Green pods plant ${ }^{-s 1}$, green pod yield plant $^{-1}$ and green pod yield

The pooled analysis of three-year data revealed that green pods plant ${ }^{-1}$, green pod yield plant ${ }^{-1}$ and green pod yield in a considerable manner among the genotypes (Table 3 and Figure 2). Green pods plant ${ }^{-1}$ ranged from 39.9 to 70.5 (Table 3). The maximum green pods plant ${ }^{-1}$ was observed for the genotype Chaumase (70.5) and the minimum number of pods plant ${ }^{-1}$ was recorded for Dhankute Chirrke (39.9). The variation in green pods plant ${ }^{-1}$ might be due to differences in the number of inflorescences, pods per raceme, flower dropping tendency of the genotypes (Khan, 2003). The highest green pod yield plant ${ }^{-1}$ was observed for the genotype Chaumase $(0.57 \mathrm{~kg})$. The lowest green pod yield plant $^{-1}$ was obtained from Bhatte $(0.35 \mathrm{~kg})$, Dhankute Chirrke
(0.36 kg), WP Con Bean (0.38 kg), White OP (0.40 kg) and Trishuli $(0.41 \mathrm{~kg})$ which were statistically identical. Similarly, the maximum green pod yield was obtained for genotype Chaumase (35.0 t/ha) and minimum yield for Bhatte (20.2 t/ha) and Dhankute Chirrke (20.5 t/ha), which were statistically identical. This higher green pod yield plant ${ }^{-1}$ and per hectare for Chaumase is attributed due to a higher number of green pods plant ${ }^{-1}$ and individual pod weight. Similar, results were reported by Pandey., et al. (2012) with the genotype Chaumase (Four Season) obtaining the greatest fresh pod yield (25.75 t/ha) at different sowing times. Similarly, the pod yield in bean was influenced by the genotype [4]. They found that the genotypes sown on the same date produced green pod plant ${ }^{-1}$ ranging from 5 to 32 .

\begin{tabular}{|c|c|c|c|c|c|c|c|c|c|c|c|c|}
\hline \multirow[b]{2}{*}{ Genotypes } & \multicolumn{4}{|c|}{ Individual pod weight (g) } & \multicolumn{4}{|c|}{ Green pods plant ${ }^{-1}$ (nos.) } & \multicolumn{4}{|c|}{ Green pod yield plant $^{-1}(\mathrm{Kg})$} \\
\hline & $\begin{array}{c}2015 \\
/ 16\end{array}$ & $\begin{array}{c}2016 \\
/ 17\end{array}$ & $\begin{array}{c}2017 \\
/ 18\end{array}$ & Mean & $\begin{array}{c}2015 \\
/ 16\end{array}$ & $\begin{array}{c}2016 \\
/ 17\end{array}$ & $\begin{array}{c}2017 \\
/ 18\end{array}$ & Mean & $\begin{array}{c}2015 \\
/ 16\end{array}$ & $\begin{array}{c}2016 \\
/ 17\end{array}$ & $\begin{array}{c}2017 \\
/ 18\end{array}$ & Mean \\
\hline Bhattte & 9.2 & 12.9 & 9.3 & $10.4 \mathrm{c}$ & 41.6 & 53.0 & 49.3 & $47.9 \mathrm{bc}$ & 0.35 & 0.37 & 0.34 & $0.35 b$ \\
\hline Chaumase & 11.5 & 18.6 & 9.6 & $13.3 \mathrm{~b}$ & 66.9 & 60.9 & 83.6 & $70.5 a$ & 0.71 & 0.37 & 0.64 & $0.57 \mathrm{a}$ \\
\hline $\begin{array}{l}\text { Dhankute } \\
\text { Chirrke }\end{array}$ & 7.9 & 10.2 & 7.9 & $8.7 \mathrm{~d}$ & 31.3 & 39.1 & 49.3 & $39.9 c$ & 0.37 & 0.39 & 0.31 & $0.36 b$ \\
\hline WP Con Bean & 9.5 & 13.5 & 8.5 & $10.5 \mathrm{c}$ & 54.5 & 50.6 & 51.0 & $52.0 \mathrm{~b}$ & 0.33 & 0.34 & 0.47 & $0.38 b$ \\
\hline White OP & 9.2 & 12.7 & 9.8 & $10.6 \mathrm{c}$ & 60.7 & 48.2 & 56.9 & $55.2 b$ & 0.31 & 0.33 & 0.55 & $0.40 \mathrm{~b}$ \\
\hline Trishuli & 11.0 & 18.1 & 15.5 & $14.7 \mathrm{a}$ & 35.3 & 36.9 & 68.5 & $46.9 \mathrm{bc}$ & 0.42 & 0.34 & 0.48 & $0.41 \mathrm{~b}$ \\
\hline Mean & 9.7 & 14.4 & 9.9 & 11.4 & 48.4 & 48.1 & 59.8 & 52.1 & 0.42 & 0.36 & 0.47 & 0.41 \\
\hline F-value & \multirow{3}{*}{\multicolumn{3}{|c|}{1.13}} & $<0.001^{* *}$ & \multirow{3}{*}{\multicolumn{3}{|c|}{$\begin{array}{l}0.08 \\
24.0\end{array}$}} & $<0.001^{* *}$ & & & & $<0.001^{* *}$ \\
\hline $\operatorname{LSD}(0.05)$ & & & & 9.43 & & & & & & & & \\
\hline CV (\%) & & & & 22.1 & & & & & & & & \\
\hline
\end{tabular}

Table 3: Performance of different genotypes of French bean for individual pod weight, green pos plant ${ }^{-1}$ and green pod yield plant ${ }^{-1}$ at HRS, Dailekh during 2016-2018.

Note: NS, * and ** indicate non-significant, significant at $\mathrm{P}<0.05$, and $\mathrm{P}<0.01$, respectively. Means followed by the same letter (s) in the column are not significantly different at $5 \%$ by DMRT.

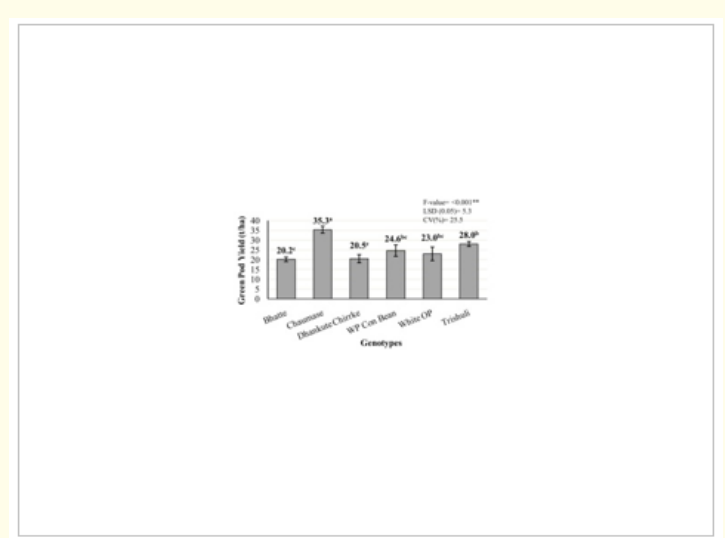

Dry pods plant ${ }^{-1}$ and dry pod yield plant ${ }^{-1}$

The pooled analysis of three-year data revealed that dry pods plant $^{-1}$ and dry pod yield plant ${ }^{-1}$ differ significantly among the genotypes (Table 4). Chaumase recorded the highest dry pods plant $^{-1}$ (53.9) which was statistically identical with White OP (47.9); whereas, the lowest number was observed in Trishuli (31.7), statistically at par with Dhankute Chirrke (317) and Bhatte (35.7). The highest dry pod yield plant ${ }^{-1}$ was recorded for Chaumase (152.2 g) and the lowest in Bhatte (80.2 g) showed the least dry pod yield plant ${ }^{-1}$.

Figure 2:Performance of different genotypes of French bean for green pod yield (t/ha) at HRS, Dailekh in 2016-2018. 
Evaluation of Pole-type French Bean (Phaseolus vulgaris L.) Genotypes for Agro-Morphological Variability and Yield in the Mid-Hills of Nepal

\begin{tabular}{|c|c|c|c|c|c|c|c|c|}
\hline \multirow{2}{*}{ Genotypes } & \multicolumn{4}{|c|}{ Dry pod plant $^{-1}$ (nos.) } & \multicolumn{4}{|c|}{ Dry pod yield plant $^{-1}(\mathrm{~g})$} \\
\hline & $2015 / 16$ & $2016 / 17$ & $2017 / 18$ & Mean & $2015 / 16$ & $2016 / 17$ & $2017 / 18$ & Mean \\
\hline Bhattte & 20.3 & 22.1 & 18.1 & $20.2 c$ & 88.3 & 86.8 & 65.4 & $80.2 c$ \\
\hline Chaumase & 38.8 & 32.3 & 33.9 & $35.0 \mathrm{a}$ & 193.8 & 182.6 & 80.1 & $152.2 \mathrm{a}$ \\
\hline Dhankute Chirrke & 21.3 & 23.7 & 16.5 & $20.5 c$ & 136.5 & 150.4 & 85.0 & $124.0 \mathrm{~b}$ \\
\hline WP Con Bean & 19.4 & 29.3 & 25.3 & $24.6 \mathrm{bc}$ & 145.9 & 145.1 & 36.7 & $109.3 \mathrm{bc}$ \\
\hline White OP & 17.9 & 21.3 & 29.6 & $22.9 \mathrm{bc}$ & 168.2 & 160.1 & 42.9 & $123.7 \mathrm{ab}$ \\
\hline Trishuli & 29.9 & 28.4 & 25.7 & $28.0 \mathrm{~b}$ & 119.3 & 120.3 & 82.6 & $107.4 \mathrm{bc}$ \\
\hline Mean & 45.6 & 45.4 & 32.2 & 41.1 & 142.0 & 140.9 & 65.5 & 116.1 \\
\hline F-value & \multirow{3}{*}{\multicolumn{3}{|c|}{6.8}} & $<0.001^{* *}$ & & & & $<0.001^{* *}$ \\
\hline LSD (0.05) & & & & 28.36 & & & & \\
\hline CV (\%) & & & & 29.6 & & & & \\
\hline
\end{tabular}

Table 4. Performance of different genotypes of French bean for dry pod yield plant ${ }^{-1}$ and dry pod yield plant ${ }^{-1}$ at HRS, Dailekh during 2016-2018.

Note: NS, * and ** indicate non-significant, significant at $\mathrm{P}<0.05$, and $\mathrm{P}<0.01$, respectively. Means followed by the same letter ( $\mathrm{s}$ ) in the column are not significantly different at $5 \%$ by DMRT.

Seeds pod $^{-1}, 100$ seed weight and seed yield

The pooled analysis of three-year data revealed that seeds pod 1,100 seed weight and seed yield differed significantly among the genotypes (Table 5 and Figure 3). Chaumase (8.2) recorded the maximum seeds pod $^{-1}$ statistically identical with Trishuli (7.9) followed by White OP (7.1) and WP Con Bean (7.1). The minimum seeds pod $^{-1}$ was found for Dhankute Chirrke (5.3) statistically identical with Bhatte (5.5). 100 seed weight was maximum for Dhankute Chirrke (60.0 g) followed by Trishuli (42.3 g), Bhatte
(39.2 g) and Chaumase (29.9 g) whereas least was recorded for WP Con Bean (23.9 g) statistically identical with White OP (24.4 g). The maximum seed yield was recorded in Chaumase $(2.1 \mathrm{~kg} /$ ha) statistically at par with Trishuli $(2.10 \mathrm{~kg} / \mathrm{ha})$ whereas, least was recorded in WP Con Bean (1.09 kg/ha). Similarly, pod and dry seed yield in bean was influenced by the genotype [4]. They found that the genotypes sown on the same date produced seed yield $(\mathrm{g} / \mathrm{m} 2)$ ranging from 5.9 to 306.5 .

\begin{tabular}{|c|c|c|c|c|c|c|c|c|}
\hline \multirow{2}{*}{ Genotypes } & \multicolumn{4}{|c|}{ Seeds pod ${ }^{-1}$ (nos.) } & \multicolumn{4}{|c|}{100 seeds weight (g) } \\
\hline & $2015 / 16$ & $2016 / 17$ & $2017 / 18$ & Mean & $2015 / 16$ & $2016 / 17$ & $2017 / 18$ & Mean \\
\hline Bhattte & 6.4 & 6.4 & 3.7 & $5.5 \mathrm{c}$ & 44.3 & 40.7 & 32.5 & $39.2 \mathrm{c}$ \\
\hline Chaumase & 8.4 & 8.8 & 7.3 & $8.2 \mathrm{a}$ & 34.7 & 31.3 & 23.7 & $29.9 d$ \\
\hline Dhankute Chirrke & 5.3 & 5.6 & 4.8 & $5.3 c$ & 65.7 & 60.6 & 53.7 & $60.0 \mathrm{a}$ \\
\hline WP Con Bean & 7.6 & 8.4 & 5.2 & $7.1 \mathrm{~b}$ & 26.0 & 24.0 & 19.2 & $23.9 \mathrm{e}$ \\
\hline White OP & 7.2 & 8.4 & 5.6 & $7.1 \mathrm{~b}$ & 26.0 & 25.0 & 19.1 & $24.4 \mathrm{e}$ \\
\hline Trishuli & 7.5 & 8.7 & 7.6 & $7.9 \mathrm{a}$ & 45.7 & 43.2 & 37.8 & $42.3 \mathrm{~b}$ \\
\hline Mean & 7.1 & 7.7 & 5.7 & 6.8 & 40.8 & 37.8 & 31.0 & 36.4 \\
\hline F-value & \multirow{3}{*}{\multicolumn{3}{|c|}{0.46}} & $<0.001^{* *}$ & & & & $<0.001^{* *}$ \\
\hline LSD (0.05) & & & & 2.2 & & & & \\
\hline CV (\%) & & & & 7.3 & & & & \\
\hline
\end{tabular}

Table 5: Performance of different genotypes of French bean for Seeds pod ${ }^{-1}$ and 100 seeds weight at HRS, Dailekh during 2016-2018. Note: NS, * and ${ }^{* *}$ indicate non-significant, significant at $\mathrm{P}<0.05$, and $\mathrm{P}<0.01$, respectively. Means followed by the same letter ( $\mathrm{s}$ ) in the column are not significantly different at $5 \%$ by DMRT. 


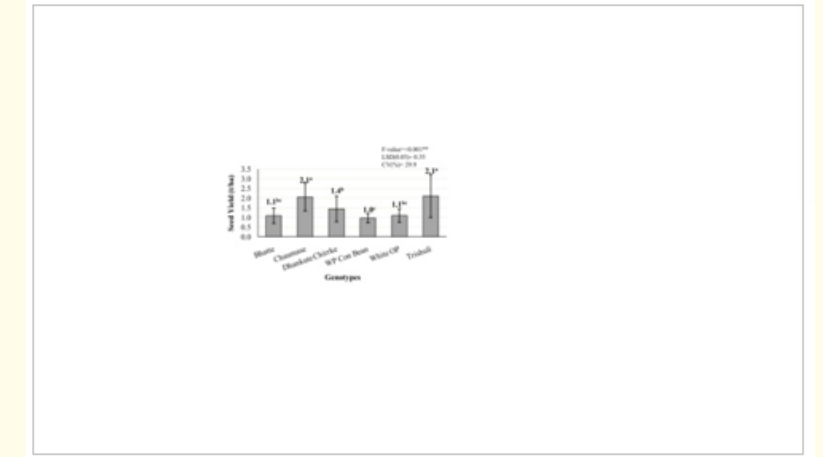

Figure 3:Performance of different genotypes of French bean for seed yield (t/ha) at HRS, Dailekh in 2016-2018.

\section{Conclusion}

The agro-morphological variation observed in the genotypes could be utilized in the selection of genotypes for varietal improvement program. Among the qualitative traits, French bean genotypes observed variability concerning stem pigmentation, leaf color, leaflet shape, stem hairiness, flower color, pod color, pod shape, pod cross-section, pod beak position, pod appearance, seed size, seed shape, and seed color. Three year mean results showed the genotype Chaumase (35.0 t/ha) followed by Trishuli $(28.0 \mathrm{t} /$ ha), WP Con Bean (24.6 t/ha) and White OP (22.9 t/ha) recorded the maximum green pod yield. Similarly, genotypes Chaumase (2.1 t/ha), Trishuli (2.1 t/ha), Dhankute Chirrke (1.44 t/ha) and White OP (1.09 t/ha) were found promising for seed production purpose. Future research work needed to be focused on the further evaluation of these genotypes under different production systems for yield and seed production and to identify traits useful for crop improvement.

\section{Acknowledgements}

The authors are highly thankful to Nepal Agriculture Research Council (NARC) for funding the experiment under the varietal development project. Sincere thanks also goes to the management team of Horticulture Research Station, Dailekh, lower technical staffs and labor which were involved during the entire production period of the experiment.

\section{Bibliography}

1. Swaider JM., et al. "Producing vegetable crops". 4th ed. Interstate Publishers, USA (1992): 626.

2. Shanmugavelu KG. "Production Technology of Vegetable Crops". Oxford and IBH Publishing Co. Pvt. Ltd., New Delhi (1989): 446-461.

3. Pandey YR., et al. "Response of Pole Type French Bean (Phaseolus vulgaris L.) Genotypes to Sowing Dates in the Mid Hills of Western Nepal". Nepal Journal of Science and Technology 13.2 (2012): 15-20.

4. Neupane RK., et al. "Agromorphological diversity in common bean (Phaseolus vulgaris L.) landraces of Jumla, Nepal". In M.C. Kharkwal, (ed.). Proceedings of the Fourth International Food Legumes Research Conference. New Delhi, India, 639-648.

5. Neupane RK and Vaidya ML. "Development of improved production technology of Phaseolus beans to the hills of mid western Nepal". In Proceedings of the First Stakeholders' Meeting. NGLRP, Rampur, Nepal (2002): 5-11.

6. IBPGR. "Descriptor List for Phaseolus vulgaris". International Board for Plant Genetic Resources, Rome (1982): 32.

7. R Core Team. "A language and environment for statistical computing". R Foundation for Statistical Computing, Vienna, Austria (2014).

8. Golani IJ., et al. "Genetic divergence in Indian bean (Lablab purpureus L.)”. Legume Research 29.4 (2006): 286-288.

9. Lenkala P., et al. "Morphological characterization of Jack bean an under exploited vegetable". Annals of Plant and Soil Research 17.2 (2015): 183-186.

10. Islam MS., et al. "Physico-morphological variation in hyacinth bean (Lablab purpureus L.)". Bangladesh Journal of agricultural research 35.3 (2010): 431-438.

11. Sultana N. "Genetic variation of morphology and molecular markers and its application to breeding in Lablab bean. Ph. D. Thesis, Kyushu University, Fukuoka, Japan (2001): 143.

12. Agarwal RL and Pawar A "Identification of soybean varieties based on seed and seedling characteristics". Seed Research 18 (1990): 77-81. 
13. Prashanth ND. "Studies on spacing and phosphorus levels on seed yield and quality and varietal identification in French bean. M.Sc. (Agri.) Thesis, University of Agricultural Sciences, Dharwad, Karnataka, India (2003).

14. Okii D., et al. "Morphological diversity of tropical common bean germplasm". African Crop Science Journal 22.1 (2014): 59-67.

15. Muchui MN., et al. "Post harvest evaluation of introduced French bean (Phaseolus vulgaris L.) varieties". African Journal of Horticultural Science 1 (2008): 116-120.

16. Neupane RK., et al. "Agromorphological diversity in common bean (Phaseolus vulgaris L.) landraces of Jumla, Nepal". Proceeding of the Fourth International Food Legumes Research Conference (IFLRC-IV) (2005): 1-11.

17. Kar A., et al. "Study on bean variability in Arunachal Pradesh". Bulletin of Arunachal Forest Research 22.1\&2 (2006): 40-44.

18. Anonymous. "Annual Report". National Bureau of Plant Genetic Resources, New Delhi 106 (2000).

19. Maass BL. "Changes in seed morphology, dormancy and germination from wild to cultivated Hyacinth bean germplasm (Lablab purpureus: Papilionoideae)". Genetic Resources and Crop Evolution 53 (2006): 1127-1135.

20. Singh, B., et al. "Morphological description of French bean varieties based on DUS characters". Indian Journal of Horticulture 71.3 (2014): 345-348.

21. Boros, L., et al. "Morphological, phenological and agronomical characterization of variability among common bean (Phaseolus vulgaris L.) local populations from the national centre for plant genetic resources: Polish genebank". Journal of Horticultural Research 22.2 (2014): 123-130.

22. Stoilova T., et al. "Diversity in common bean landraces (Phaseolus vulgaris L.) from Bulgaria and Portugal”. Journal of Central European Agriculture 6.4 (2005): 443-448.

23. Bode D., et al. "Morphological characterization and interrelationships among descriptors in Phaseolus vulgaris accessions". Agriculture and Forestry 59.2 (2013): 175- 185.

24. Pandey YR., et al. "Variability of French Bean in the Western Mid Hills of Nepal”. Kasetsart Journal of Natural Sciences 45 (2011): 780- 792.
25. Pengelly BC. and Maass BL. "Lablab purpureus (L.) Sweet-diversity, potential use and determination of a core collection of this multi-purpose tropical legume". Genetic Resources and Crop Evolution 48 (2001): 261-272.

26. Khan MMR. "Performance of lablab bean genotypes under different supports". MS. Thesis, Department of Horticulture, BSMRAU, Salna, Gazipur 76 (2003).

Volume 3 Issue 12 December 2019 (c) All rights are reserved by Santosh Kalauni., et al. 